\title{
PRECISE MAPPING OF THE EGF RECEPTOR GENE ON THE HUMAN CHROMOSOME 7p12 USING AN IMPROVED FISH TECHNIQUE
}

\author{
Yimin Wang, Shinsei Minoshima, and Nobuyoshi Shrmizu* \\ Department of Molecular Biology, Keio University School of Medicine, \\ 35 Shinanomachi, Shinjuku-ku, Tokyo 160, Japan
}

\begin{abstract}
Summary The gene for epidermal growth factor receptor (EGFR) has been localized to the p14-p12 region of human chromosome 7 by somatic cell hybridization and radioisotope in situ hybridization techniques. In this paper, we report the precise mapping of the EGFR gene to the band p12 of chromosome 7 using a novel method in which fluorescence images from in situ hybridization and Q-banding are computer graphically merged. The novel procedure is described in detail.
\end{abstract}

Key Words EGF receptor, gene mapping, FISH

\section{INTRODUCTION}

Epidermal growth factor receptor (EGFR) is a membrane spanning glycoprotein with a MW of 170,000 daltons. It is localized on the membrane surface of various types of mammalian cells including human cells (Adamson and Rees, 1981; Behzadian et al., 1982; Damjanov et al., 1986). EGFR is expressed generally in proliferating cells and its expression ceases when the cells achieve terminal differentiation (Fukuyama and Shimizu, 1991). Overexpression of the EGFR was initially found in an epithelial cell line (A431) of squamous cell carcinoma origin (Fabricant et al., 1976) and it was correlated with a unique marker chromosome by somatic cell hybridization studies (Shimizu et al., 1984). Because EGFR had a significant similarity to a viral oncogene $\mathrm{v}$-erb $\mathrm{B}$ producing protein tyrosine kinase activity, the EGFR became an intensive focus on tumor molecular biology (Shimizu, 1992).

The gene responsible for producing EGFR proteins was assigned to human chromosome 7, particularly in the region of p13-q22 by somatic cell hybridization technique (Shimizu et al., 1980; Kondo and Shimizu, 1983) and later localized to the p14-p12 region of that chromosome using radioisotope in situ hybridization

Received October 12, 1993; Revised version received and accepted November 2, 1993.

*To whom correspondence should be addressed. 
technique (Merlino et al., 1985). Furthermore, overexpression of EGFR was found at a significant rate in various tumors including squamous cell carcinoma of lung, esophagus, vulva, and tongue (Gill et al., 1985; Hunts et al., 1985a, 1985b; Yamamoto et al., 1986; Ozawa et al., 1987, 1988; Kaseda et al., 1989) and amplification of the EGFR gene was found to be a major cause of overproduction. The structure of EGFR-containing amplicon was unique and relatively large (Kawasaki et al., 1988). The following reports a precise mapping of the EGFR gene to the middle of the band $7 \mathrm{p} 12$ using a new method in which signals from fluorescent in situ hybridization (FISH) and Q-banding were computer graphically merged to generate map information.

\section{MATERIALS AND METHODS}

Fluorescence in situ hybridization (FISH). Metaphase chromosome preparation was made from human diploid B-lymphoblastoid GM130B cells as described previously (Fukuyama et al., 1991). The EGFR gene probe used was a mixture of human cDNA clone pLsx and genomic DNA clone pERP8 (Kawasaki et al., 1988). FISH was carried out as previously described with several modifications (Fukuyama et al., 1991). Briefly, the plasmid pLsx clone cDNA and genomic pERP8 clone DNA was individually labeled with digoxigenin-11-dUTP (BRL) by nick translation. The reaction mixture $(50 \mu \mathrm{l})$ contained $1 \mu \mathrm{g}$ plasmid clone DNA; dCTP, dATP, dGTP, and digoxigenin-11-dUTP (20 mm each); DNA polymerase I ( 2 units, BRL); and DNase I ( $\mu \mathrm{g})$. Probe DNA $136.5 \mathrm{ng}$ was mixed with 10 $\mu l$ of hybridization solution and used for one hybridization sample. Immunological detection of hybridization was carried out using FITC-conjugated sheep anti-digoxigenin antibody (Boehringer Mannheim $\mathrm{GmbH}$, Germany) and FITCconjugated donkey anti-sheep immunoglobulin antibody (Silenus, Australia). Chromosomes were counter-stained with propidium iodide (PrI, $10 \mathrm{ng} / \mathrm{ml}$ ). The fuorescence image of probe hybridization was analyzed by confocal laser scanning microscope MRC-600 (Bio-Rad, Richmond, CA). The position of the chromosome spread on the slide was recorded by a ruler on the microscope.

$Q$-banding. After recording the FISH images of EGFR gene, slides were washed with Macllvaine's buffer ( $\mathrm{pH} \mathrm{5.0)}$ for $10 \mathrm{~min}$, then stained with quinacrine mustard (QM, $20 \mathrm{mg} / \mathrm{ml}$, Sigma) in Macllvaine's buffer for $20 \mathrm{~min}$ and washed in the same buffer for an additional $20 \mathrm{~min}$. Q-banding image was also recorded and analyzed by the MRC-600 system. Freshly prepared slides are essential for good banding. Thus, three different fluorescent images: FISH probe signals, PrI counter-stained chromosomes and Q-banded chromosomes from the same chromosome spread were obtained. The edge enhancing function of a software, $\mathrm{CO}$ MOS (Bio-Rad), was applied to the Q-banding image.

Merging fluorescent images from FISH and Q-banding. By utilizing the MRC600 software system, it is possible to objectively merge two fluorescent images ob- 
tained separately from the same chromosome sample. First, the mixed fluorescent image of FITC signals and PrI counter-stained chromosomes was displayed on the computer screen, and the location of the chromosome spread was recorded by making some measurement on the screen. Next, the Q-banded chromosome spread was adjusted at the same position as the FISH image and recorded with the same magnification, and then, merged with PrI counter-stained chromosome image by MRC-600 system. Usually, two images can not be exactly merged by adjusting the position of the slide holder on the microscope. However, by adjusting the position of Q-banded chromosome set on a screen through image edit function of the software, two images were exactly merged. The contours and centromere regions of the chromosomes are two useful indexes to merge two chromosome sets. Finally, images for the FITC signal and Q-banded chromosomes are merged and given pseudo red signals for FITC and green signals for Q-banded chromosomes. Signal appearing chromosomes can be zoomed larger to finally check the precise overlap of two merged chromosome sets.

Arbitrary reference point ( $A R P$ ) analysis. The map position of the EGFR gene was also expressed as a numeric value of the arbitrary reference point (ARP) system (Human Gene Mapping 10, 1989; Fukuyama et al., 1991), in which the centromere, telomeres of short arm and long arm were given a numeric value of $0,+100$, and -100 , respectively. The relative positions of boundaries of Q-positive and Q-negative bands were also measured. At least 10 pairs of FISH and Q-banded chromosome images were used for the measurement. The length of the short arm was determined from the PrI stained chromosome image instead of the Qbanded one because Q-negative telomeres are not clear. The assignment of the EGFR gene to a particular region was done by comparing those relative values.

\section{RESULTS}

Metaphase chromosome preparation was hybridized with a mixed DNA probe for the EGFR gene, and hybridization signal was amplified with FITC-conjugated antibodies and counter-stained with PrI. As seen in Fig. 1a, a pair of FITC signals were located on each of the short arms of two $\mathrm{C}$ group chromosomes. This same chromosome preparation was then Q-banded. Q-banding clearly shows that the signal bearing chromosomes are chromosome 7 (Fig. 1b). The image of PrI-stained chromosomes were then merged with the image of Q-banded chromosomes. With extremely careful alignment, an objectively merged image can be generated as shown in Fig. 1c. Then, FITC signals from cDNA probes can be exhibited on Q-banded patterns (Fig. 1d). In this image, FITC signals were changed artificially to a red color by MRC- 600 system. As seen, FITC signals overlapped on the Q-bands looked yellow due to mixing to red and green colors. The positions of the EGFR gene signals on the chromosomes in Fig. 1a and $1 \mathrm{~d}$ are exactly coincided. From Fig. $1 \mathrm{~d}$, it is clear that the EGFR gene locates on the band p12 of chromosome 7. 

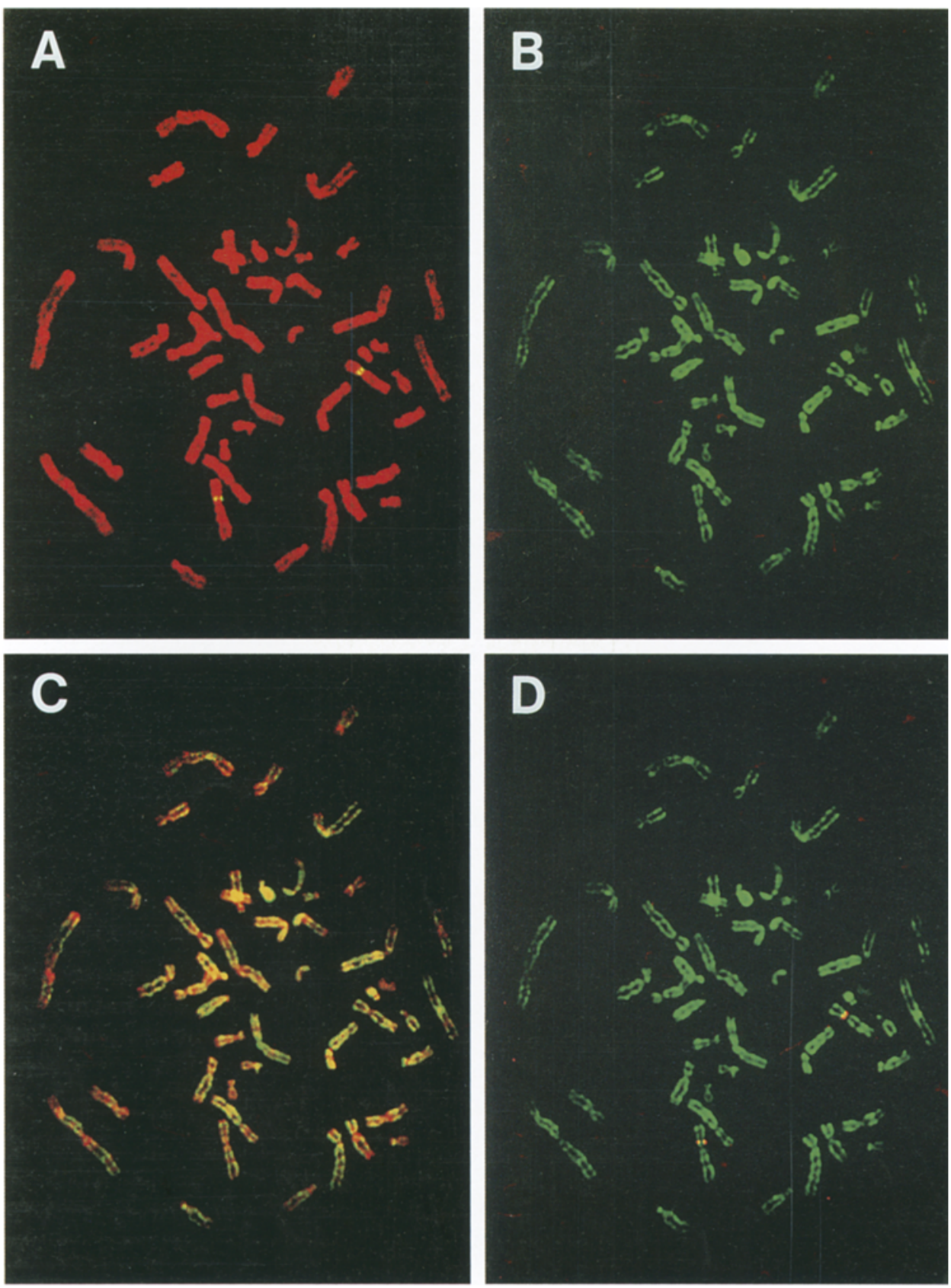

Fig. 1. The process of merging various fluorescent images. (a) FTTC signals of EGFR gene probe on the PrI counter-stained metaphase chromosomes. (b) Metaphase chromosomes after Q-banding. The same chromosome spread as Fig. 1a. (c) Merged image of PrI counter-stained chromosomes with Q-banded chromosomes. (d) Merged image of probe FITC signals with Q-banded chromosomes. 


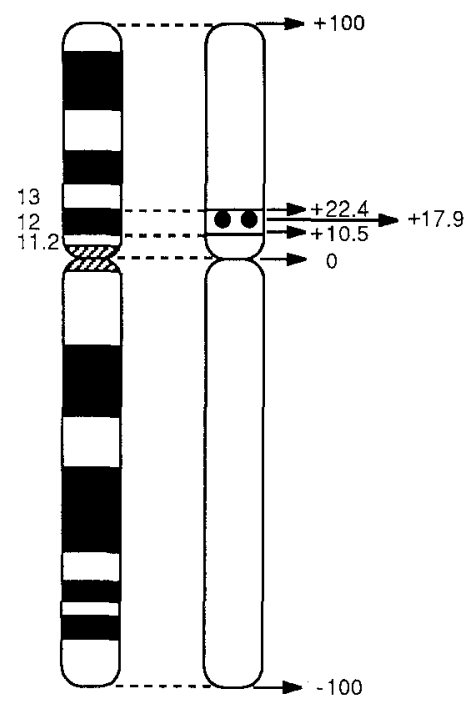

Fig. 2. The numeric value of EGFR gene location. The EGFR gene is located at +17.9 , between the two edges of the Q-positive band 12 of human chromosome 7.

To further evaluate the accuracy of the above described image merging method, arbitrary reference position (ARP) analysis was performed. ARPs were determined for each chromatid from 10 pairs of Q-banded chromosomes and FISH images and results were summarized in Fig. 2. The boundaries of Q-positive band p12 were determined as +10.5 and +22.4 , respectively, whereas FISH signals were located at +17.9 . Comparison of these ARP values enabled us to precisely localize the EGFR gene on the band 7p12. Thus, the EGFR gene is located within the band $7 \mathrm{p} 12$, almost in the middle of this small region.

\section{DISCUSSION}

Mapping of a large number of DNA probes to individual chromosomes is a challenging problem in analyzing the complex human genome. The most advanced method for identifying the chromosomal locus of a human DNA segment is FISH (Bhatt and McGee, 1990). The combination of FISH signals with chromosome banding is essential for precise gene mapping. Many banding techniques such as G-banding, R-banding, Q-banding and DAPI staining have been available for this purpose. Each of these techniques has some merits as well as shortcomings. For example, G-banding shows no fluorescence and therefore the combination of G-banded chromosomes with FISH signals is not feasible. R-banding has been successfully used (Takahashi et al., 1991) but requires skilled technique and is limited to certain cells. DAPI staining is convenient, but the banding is not sharp and FITC signals are suppressed to some degree. In the Q-banded chromosomes, 
FITC probe signals can not be detected because both show green fluorescence excited by the same wave length. Texas Red (TR) has been used successfully (Fukuyama and Shimizu, 1992) and similar fluorescent dyes like rhodamine can be used.

The method used here however does not depend on the types of fluorescent dyes to detect probe signals because two separately obtained fluorescent images are computer graphically merged with the aid of the MRC-600 system providing artificial colors. The accuracy of merging two images can be judged and confirmed with the ARP analysis. In the ARP analysis, the accuracy of chromosome length measurement mainly rely on the recognition of centromeres. In our method, the merging of two images depend not only on the position of the centromere but also on entire shapes of the chromosome including length and width. Even some special traits on the spread can be used as an anchor point for precise positioning. Recording probe signals and PrI counter-stained chromosomes can be performed without changing the position of chromosome slide on a microscope. Once the PrI-stained chromosome image was precisely matched with the Q-banded one, positions from probe signal are automatically located on the Q-banded chromosomes. Therefore, the merging of probe signals with Q-banding is objective and accurate.

The mapping of the EGFR gene has been reported on several occasions (Shimizu et al., 1980; Kondo and Shimizu, 1983; Merlino et al., 1985). By radioisotope in situ hybridization, the gene was localized to the p14-p12 region of chromosome 7 (Merlino et al., 1985). More recently, Habets et al. (1992) localized the EGFR gene to $7 \mathrm{p} 12$ by Southern blot analysis of cell hybrids containing various regions of human chromosome 7. Most important hybrid clone A-1 containing the 7p12-qter fragment was positive for EGFR probe hybridization. However, the exact break point of this chromosome fragment was not clearly described. Nevertheless, comparing with the previously published data suggesting the location of the p14-p12, they concluded the location of p12. This assignment was quite indirect. Now, the FISH technique combined with a new method of image merging made it possible to definitely localize the EGFR gene on the band p12 of chromosome 7. The band p12 occupies approximately one twentieth of the well condensed metaphase chromosome 7 which contains $160 \mathrm{Mb}$ of DNA (Fig. 2; Southern, 1982). Assuming the uniform condensation of DNA throughout chromosome, the EGFR gene is located within a DNA segment of $8 \mathrm{Mb}$. The precise mapping of human EGFR gene is valuable information for further cancer study and human genome analysis.

Acknowledgments This work was supported by a Grant-in-Aid for a Creative Basic Research (Human Genome Program) from The Ministry of Education, Science and Culture of Japan. We thank Ms. H. Harigai for her excellent assistance in manuscript preparation. 


\section{REFERENCES}

Adamson ED, Rees AR (1981): Epidermal growth factor receptors. Mol Cell Biochem 34: 129152

Behzadian MA, Shimizu Y, Kondo I, Shimizu N (1982): Genetics of receptors for bioactive polypeptides: Expression of the human EGF receptor gene and internalization and processing of the receptor-bound EGF in human-mouse cell hybrids. Somat Cell Genet 8: 347-362

Bhatt B, McGee JO'D (1990): In situ hybridization. In: Polak JM, McGee JO’D (eds). Principle and practice. Oxford Sci Pub, New York, pp 149-164

Damjanov I, Mildner B, Knowles BB (1986): Immunohistochemical localization of the epidermal growth factor receptor in normal human tissue. Lab Invest 55: 588-592

Fabricant RN, DeLarco JE, Todaro J (1976): Nerve growth factor receptor on human melanoma cells in culture. Proc Natl Acad Sci USA 74: 565-569

Fukuyama R, Ichijou Y, Minoshima S, Kitamura N, Shimizu N (1991): Regional localization of the hepatocyte growth factor (HGF) gene to human chromosome 7 band q21.1. Genomics 11: $410-415$

Fukuyama R, Shimizu N (1991): Expression of epidermal growth factor (EGF) and the EGF receptor in human tissues. J Exp Zool 258: 336-343

Fukuyama R, Shimizu N (1992): Detection of variation in the ribosomal RNA gene clusters by a modified fluorescence in situ hybridization method. Jpn J Human Genet 37: 139-143

Giil GN, Weber W, Thornpson DM, Lin C, Evans RM, Rosenfeld MG, Gamou S, Shimizu N (1985): Relationship between production of epidermal growth factor receptors, gene amplification, and chromosome 7 translocation in variant A431 cells. Somat Cell Mol Genet 11: 309-318

Habets GGM, van der Kammen RA, Willemsen V, Balemans M, Wiegant J, Collard JG (1992): Sublocalization of an invasion-inducing locus and other genes on human chromosome 7 . Cytogenet Cell Genet 60: 200-205

Human Gene Mapping 10 (1989): Tenth International Workshop on Human Gene Mapping. Cytogenet Cell Genet 51: 622-947

Hunts J, Ueda M, Ozawa S, Abe O, Pastan I, Shimizu N (1985a): Hyperproduction and gene amplification of the EGF receptor in squamous cell carcinomas. Jpn J Cancer Res (Gann) 76: $663-666$

Hunts JH, Shimizu N, Yamamoto T, Toyoshima K, Merlino GT, Xu Y-H, Pastan I (1985b): Translocation chromosome 7 of A431 cells contains amplification and rearrangement of EGF receptor gene responsible for production of variant mRNA. Somat Cell Mol Genet 11: 477-484

Kaseda S, Ueda M, Ozawa S, Ishihara T, Abe O, Shimizu N (1989): Expression of epidermal growth factor receptors in four histologic cell types of lung cancer. J Surg Oncol 42: 16-20

Kawasaki K, Kudoh J, Shimizu N (1988): Mega base map of the EGF receptor gene flanking regions and structure of the amplification units in EGF receptor-hyperproducing squamous carcinoma cells. Jpn J Cancer Res (Gann) 79: 1174-1183

Kondo I, Shimizu N (1983): Mapping of the human gene for epidermal growth factor receptor (EGFR) on the p13-q22 region of the chromosome 7. Cytogenet Cell Genet 35: 9-14

Merlino GT, Ishii S, Whang-Peng J, Knutsen T, Xu Y-H, Clark AJL, Stratton RH, Wilson RK, Ma DP, Roe BA, Hunts JH, Shimizu N, Pastan I (1985): Structure and localization of the genes encoding the aberrant and normal epidermal growth factor receptor RNAs from A431 human carcinoma cells. Mol Cell Biol 5: 1722-1734

Ozawa S, Ueda M, Ando N, Abe O, Shimizu N (1987): High incidence of EGF receptor-hyperproduction in esophageal squamous cell carcinomas. Int J Cancer 39: 333-337

Ozawa S, Ueda M, Ando N, Abe O, Shimizu N (1988): Epidermal growth factor receptors in cancer

Vol. 38, No. 4, 1993 
tissues of esophagus, lung, pancreas, colorectum, breast and stomach. Jpn J Cancer Res (Gann) 79: $1201-1207$

Shimizu N, Behzadian MA, Shimizu Y (1980): Genetics of cell surface receptors for bioactive polypeptides: Binding of epidermal growth factor is associated with the presence of human chromosome 7 in human-mouse cell hydrids. Proc Natl Acad Sci USA 77: 3600-3604

Shimizu N, Kondo I, Gamou S, Behzadian MA, Shimizu Y (1984): Genetic analysis of hyperproduction of epidermal growth factor receptors in human epidermoid carcinoma A431 cells. Somat Cell Mol Genet 10: 45-53

Shimizu N (1992); Epidermal growth factor receptors in lung cancer. In: Bernal SD, Baylin S (eds), Lung biology in health and disease "lung cancer differentiation." Marcel Dekker Inc, New York, pp 137-158

Southern EM (1982): Application of DNA analysis to mapping the human genome. Cytogenet Cell Genet 32: 52-57

Takahashi E, Yamauchi M, Tsui H, Hitomi A, Meuth M, Hori T (1991): Chromosome mapping of the human cytidine-5'-triphosphate synthetase (CTPS) gene to band 1p34.1-p34.3 by fluorescence in situ hybridization. Hum Genet 88: 119-121

Yamamoto T, Kamata N, Kawano H, Shimizu S, Kuroki T, Toyoshima K, Rikimaru K, Nomura N, Ishizaki R, Pastan I, Gamou S, Shimizu N (1986): High incidence of amplification of the EGF receptor gene in human squamous carcinoma cell lines. Cancer Res 46: 414-416 